\title{
Features of Sexual Reproduction and Mating System of Ulnaria acus (Bacillariophyta)
}

\author{
Yulia A. Podunay*a, Nickolai A. Davidovich ${ }^{\mathrm{a}}$, \\ Maxim S. Kulikovskiy ${ }^{\mathrm{b}}$ and Evgenii S. Gusev ${ }^{\mathrm{b}}$ \\ ${ }^{a}$ T.I. Vyazemsky Karadag Scientific Station- \\ Nature Reserve of the RAS \\ 24 Nauki Str., Kurortnoe, Feodosia, 298188, Russia \\ ${ }^{b}$ Papanin Institute for Biology of Inland Waters RAS \\ Borok, Yaroslavl oblast, 152742, Russia
}

Received 28.04.2016, received in revised form 28.06.2016, accepted 29.06.2016, published online 10.11.2017

Sexual reproduction and mating system of the freshwater diatom Ulnaria acus (Bacillariophyta) was described for the first time. Mating system of the species includes, apparently, only heterothallic way of reproduction: during the three-year observation period neither male nor female clones have shown the ability to reproduce homothallically. The type of sexual reproduction is cis-anisogamous; in many details it similar with reproduction of closely related species Ulnaria ulna, Tabularia fasciculata, and Tabularia tabulata.

Keywords: Ulnaria acus, mating system, sexual reproduction, gametogenesis, auxospore.

Citation: Podunay Yu.A., Davidovich N.A., Kulikovskiy M.S., Gusev E.S. Features of sexual reproduction and mating system of Ulnaria acus (Bacillariophyta). J. Sib. Fed. Univ. Biol., 2018, 11(1), 75-87. DOI: 10.17516/1997-1389-0034.

(c) Siberian Federal University. All rights reserved

* Corresponding author E-mail address: yu.podunai@yandex.ru 


\title{
Особенности полового воспроизведения
}

\section{и система скрещивания Ulnaria acus (Bacillariophyta)}

\author{
Ю.А. Подунайа \\ М.С. Куликовскийб ${ }^{\sigma}$ Е.С. Гусев ${ }^{\sigma}$ \\ ${ }^{a}$ Карадагская научная станиия им. Т.И. Вяземского - \\ природный заповедник РАН \\ Россия, 298188, Республика Крым, Феодосия, \\ пос. Курортное, ул. Науки, 24 \\ ${ }^{6}$ Институт биологии внутренних вод им. И.Д. Папанина РАН \\ Россия, 152742, Ярославская обл., пос. Борок
}

\begin{abstract}
Впервые описано половое воспроизведение и система скрещивания пресноводной диатомовой водоросли Ulnaria acus (Bacillariophyta). Система скрещивания изучаемого вида включает, повидимому, только гетероталлический способ воспроизведения: ни мужские, ни женские клонь на протяжении трехлетнего периода наблюдений не показалиспособностикгомоталлическому воспроизведению. Половое воспроизведение иис-анизогамного типа, во многих деталях оно напоминает воспроизведение близкородственных Ulnaria ulna, Tabularia fasciculata, Tabularia tabulata.
\end{abstract}

Ключевые слова: Ulnaria acиs, система скрещивания, половое воспроизведение, гаметогенез, ауксоспора.

\section{Введение}

Пресноводная бесшовная диатомовая водоросль Ulnaria acus s.l. (Kützing) M.Aboal один из доминантных видов фитопланктона оз. Байкал (Поповская, Генкал, 1998), который вносит существенный вклад в пищевые цепи и круговорот кремния, а также является биостратиграфическим маркером байкальской палеолетописи плейстоцена и голоцена (Grachev et al., 1998). В настоящее время необходимо рассматривать Ulnaria acus в широком смысле, поскольку этот видовой комплекс, как и весь род Ulnaria (Kützing) Compère, подвергается тщательной ревизии с типификацией видов (Lange-Bertalot, Ulrich, 2014) и с выделением новых видов, как, например, U. ferefusiformis Kulikovskiy, Lange-Bertalot и U. pilum Kulikovskiy, Lange-
Bertalot (Kulikovskiy et al., 2016). Как важный для байкальской флоры вид $U$. acus изучалась с разных сторон. Детально исследована ультраструктура клеток, описан на разных стадиях морфогенез элементов панциря (Бедошвили и др., 2007), цитология хлоропластов (Бедошвили и др., 2009). Изучен химический состав клеток (Petrova et al., 2013), описаны механизмы биоминерализации и транспорта кремниевой кислоты внутрь клетки (Grachev et al., 2002; Grachev et al., 2005). B последние годы большое внимание уделено изучению генома вида, получена последовательность хлоропластных генов (Galachyants et al., 2012), полностью расшифрован митохондриальный геном (Ravin et al., 2010). Был отработан метод культивирования U. acus в больших емкостях для получения биогенно- 
го кремнезема, белков и липидов, в том числе эйкозапентаеновой кислоты (Vereshchagin et al., 2008). Описана микрофлора, ассоциированная с клетками вида, влияние которой может приводить к их гибели в культуре (Zakharova et al., 2010).

Несмотря на столь значительные успехи в изучении $U$. acus, биология воспроизведения и система скрещивания вида оставались до настоящего времени невыясненными. Результаты наших экспериментов и наблюдений позволяют восполнить этот пробел. В настоящей работе дано описание полового воспроизведения, жизненного цикла и системы скрещивания U. acus. Полученные данные помимо фундаментального имеют прикладное значение; они необходимы, в частности, для успешного содержания вида в культурах, как лабораторных, так и биотехнологических.

\section{Материалы и методы}

Три клона Ulnaria acus (ранее Synedra acus Kützing 1844) выделены из популяции оз. Фролиха, которое рекой с одноименным названием соединяется с оз. Байкал в северо-восточной его части. Пробы собраны в июле 2012 г. М.С. Куликовским, изолированы в культуры Е.С. Гусевым: В114, В118 - из планктонных проб, собранных в районе Большого Ушканьего острова (5351'129" с.ш., $108^{\circ} 35^{\prime} 795^{\prime}$ ' в.д.); В119 - из планктонных проб, собранных в бухте Солнечная (5417'327' ' с.ш., $108^{\circ} 29^{\prime} 106^{\prime}$ ' в.д.). Температура воды в изученных местах была около $17{ }^{\circ} \mathrm{C}$, проводимость 111 мкСм/см. Измерения минерализации и температуры воды были выполнены с использованием прибора Hanna Combo (HI 98129), Hanna Instruments, Inc., США. В дальнейшем в экспериментах по скрещиванию также были использованы шесть клонов - потомков первого поколения (F1), которые были получены из инициальных клеток от воспроизведения «диких» родительских клонов.

Культуры содержали на среде, близкой по составу к среде Dm (Mann, Chepurnov, 2004). Клетки для клоновых культур выделяли микропипеточным методом (Гайсина и др., 2008) под микроскопом МБС-9 (ЛОМО, (CСР), очищали с помощью многократного пересева в свежую среду. Культивирование проводили в стеклянных чашках Петри диаметром 5-9 см, высотой 0,9-1,4 см при наполнении средой от 8 до 45 мл соответственно размеру чашки. Экспоненциальную фазу роста поддерживали еженедельным пересевом в свежую питательную среду. Монокультуры постоянно просматривали под микроскопом на предмет обнаружения случаев гомоталлического воспроизведения. Чашки находились в изолированной комнате с постоянной температурой $(20 \pm 2){ }^{\circ} \mathrm{C}$ на полках у окон, обращенных на север, - таким образом, обеспечивали естественное освещение. Однако поскольку оптимальной для роста $U$. acus является температура $12-14{ }^{\circ} \mathrm{C}$, то экспериментальные чашки со скрещенными посевами содержали при температуре $14-16{ }^{\circ} \mathrm{C}$. Обильность воспроизведения оценивали в баллах: 0 - воспроизведения не было, 1 - единичные случаи гаметогенеза/ауксоспорообразования, 2 - случаи гаметогенеза/ауксоспорообразования встречаются часто, но их нельзя назвать массовыми, 3 - массовое аукспорообразование.

Наблюдения проводили под микроскопом Biolar PI (PZO, Польша) методом дифференциально-интерференционного контраста и освещения по Кёлеру (Федин, Барский, 1971). Фотографии выполнены с помощью цифровой фотокамеры Canon PowerShort А640. Размер клеток определяли с помощью окулярной линейки, калиброванной по объект-микрометру. Электронные микро- 
фотографии сделаны на сканирующем электронном микроскопе JEOL JSM-5600 (ИБВВ РАН, Борок).

\section{Результаты}

Морфологическая характеристика

Вегетативные клетки U. acus прикрепляются к субстрату одним концом с помощью слизи, располагаясь по одной клетке или образуя небольшие колонии. Достаточно большое количество клеток не прикрепляется к субстрату, находясь в среде во взвешенном состоянии. Клетки вытянутые, имеют узко- ланцетную форму створки (рис. 1). Диапазон размеров вегетативных клеток $U$. acus, coдержавшихся в культуре, составил от 42 до 360 мкм. В клоновых культурах в результате вегетативного размножения длина клеток постоянно уменьшалась со средней скоростью $(5,7 \pm 1,1)$ мкм/месяц (рассчитано как средневзвешенное значение зависимого коэффициента уравнения линейной регрессии, полученное для пяти клонов, рис. 2). Для большинства исследованных клонов были также отмечены случаи спонтанного скачкообразного уменьшения длины клеток (рис. 1Б). Апикальный
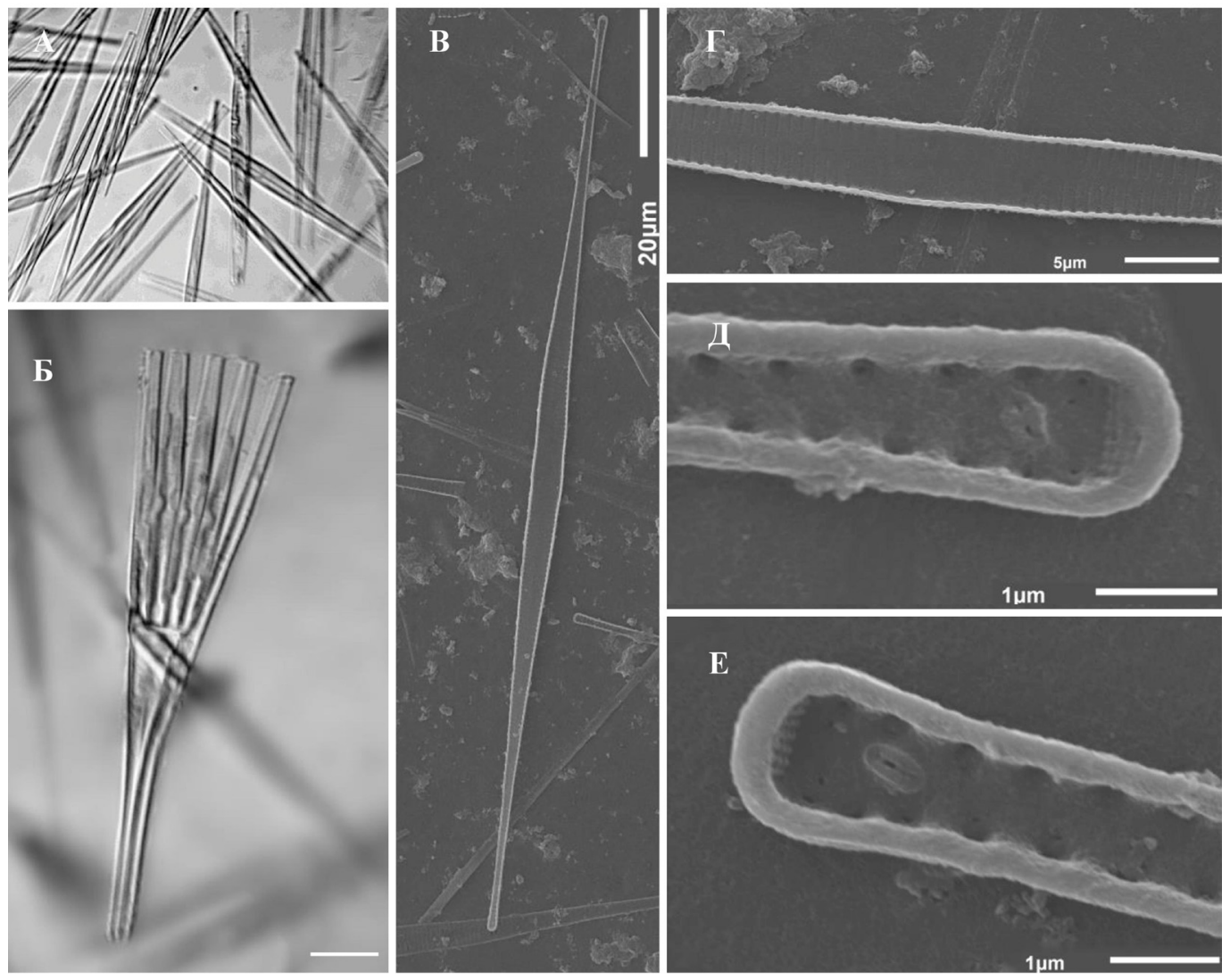

Рис. 1. Внешний вид клеток Ulnaria acus: А - клетки на дне чашки Петри (световая микроскопия (х600)); Б - клетка с неправильным митотическим делением, при котором новообразованные клетки имеют меньшую апикальную длину (масштабный отрезок 20 мкм); В - Е - электронные микрофотографии клетки

Fig. 1. External view of Ulnaria acus cells. A - cells on the bottom of a Petri dish (light microscopy (x600)); Б - cell with an incorrect mitotic division, the newly formed cells have a smaller apical length (scale $20 \mu \mathrm{m}$ ); $\mathrm{B}-\mathrm{E}$ - scanning electron micrographs of the cell 


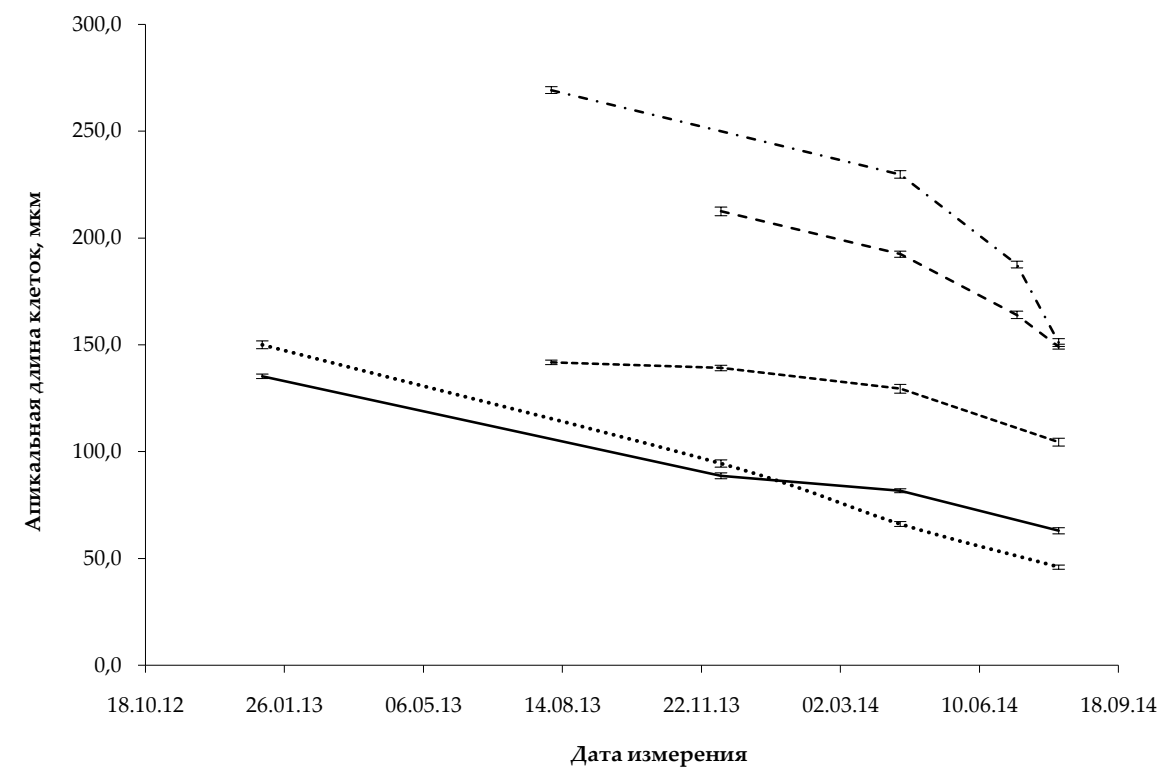

Рис. 2. Уменьшение длины клеток в пяти клонах Ulnaria acus при содержании в культуре. Каждая точка представляет среднюю величину $( \pm \mathrm{SE})$, полученную в результате измерения десяти клеток клона

Fig. 2. Decrease of the apical cell length in Ulnaria acus clones growing in cultures. Each point represents the mean \pm SE of ten measurements

Таблица 1. Апикальная длина клеток Ulnaria acus

Table 1. The apical size of Ulnaria acus cells

\begin{tabular}{|l|c|c|c|}
\hline \multirow{2}{*}{\multicolumn{1}{|c|}{ Стадии жизненного цикла }} & \multicolumn{3}{|c|}{ Длина клеток, мкм } \\
\cline { 2 - 4 } & $\min$ & $\max$ & 486 \\
\hline Вегетативные клетки & 42 & 360 & 140 \\
Гаметангии & 62 & 194 & 137 \\
Инициальные клетки & 208 & 360 & $\mathrm{n}$ \\
\hline
\end{tabular}

Примечание: $\min$ - наименьшая длина клеток, наблюдавшаяся в культуре; $\max$ - наибольшая длина клеток, наблюдавшаяся в культуре; $\mathrm{n}$ - количество измерений.

размер (=длина) клеток в культурах, находящихся на разных стадиях жизненного цикла, представлен в табл. 1. Апикальный размер гаметангиальных клеток варьировал от 62 до 194 мкм, длина наибольших инициальных клеток 360 мкм. Между размером родительских клеток, участвующих в половом воспроизведении, и размером образующихся инициальных клеток отмечена весьма слабая корреляция (рис. 3), коэффициент которой равен 0,35 .

\section{Особенности гаметогенеза}

На третьи - четвертые сутки после посева смешанных клонов противоположного пола наблюдали аллогамный половой процесс. Половой процесс в большинстве случаев наступал в пучках клеток, прикрепленных к субстрату. При этом в пучке могли находиться клетки разного пола, что можно было хорошо видеть при скрещивании двух клонов, клетки которых хорошо различаются по апикальной длине. Клетки, в которых 


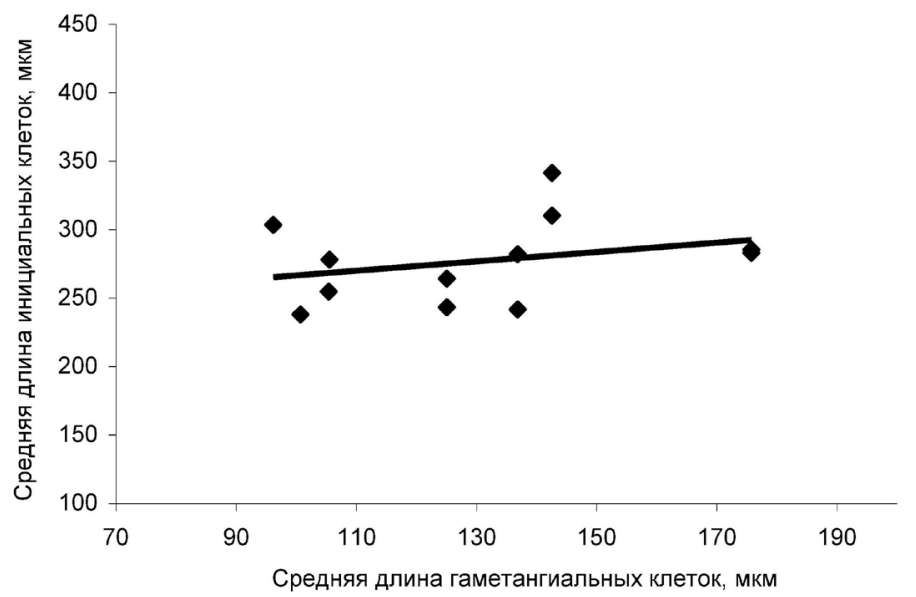

Рис. 3. Зависимость длины инициальных клеток Ulnaria acus от длины гаметангиев. Длину клеток гаметангиев рассчитывали как среднее из средних размеров клеток в паре клонов; длина инициальных клеток рассчитывалась как средняя длина инициальных клеток, возникших в смеси родительских клонов

Fig. 3. Relationship between the lengths of the gametangia and the lengths of the initial cells derived from them in Ulnaria acus. Gametangial cell length was calculated as the average of mean cell sizes in a pair of clones; initial cell length was calculated as the average length of initial cells arisen in the mixture of parental clones

начинался гаметогенез, отличались появлением вакуолей (рис. 4). На заключительных этапах образования гаметы, производимые мужскими и женскими гаметангиями, были морфологически идентичными (имели круглую форму) и отделялись от створок. Однако на начальных этапах способы формирования мужских и женских гамет отличались. Деление содержимого мужского гаметангия происходило в трансапикальной плоскости. Вначале гаметы имели продолговатую форму и лежали внутри створок родительской клетки, затем они укорачивались, округлялись и, раздвигая створки гаметангия, выходили наружу (рис. 4Д). В женском гаметангии деление происходило в апикальной плоскости. Женские гаметы в начале своего развития располагались пристенно, каждая гамета у своей створки раскрывшегося гаметангия. Затем они постепенно округлялись и теряли связь со створкой. Развитие гамет в гаметангиях (как женских, так и мужских) было не вполне синхронным, часто одна гамета проходила весь путь развития, вплоть до полного округления, быстрее другой. Особенно наглядно это происходило при формировании гамет в женских гаметангиях (рис. $4 A-\Gamma$ ). У некоторых гамет (предположительно мужских) нами была обнаружена способность к вращению. Последующее изучение показало наличие у вращающихся гамет появляющихся и исчезающих тонких цитоплазматических выростов - структур, напоминающих псевдоподии (рис. $5 B, \Gamma, Ж)$ ). Их наличие не было перманентным: после выхода из гаметангия гаметы были сферическими, на поверхности отсутствовали какие-либо выросты. Спустя минуту или несколько минут поверхность гаметы становилась активной, сначала появлялись короткие цитоплазматические выросты, которые быстро удлинялись. Затем, «наматываясь» на клетку, они провоцировали ее вращение и хаотическое движение. Спаривания родительских гаметангиев для копуляции 

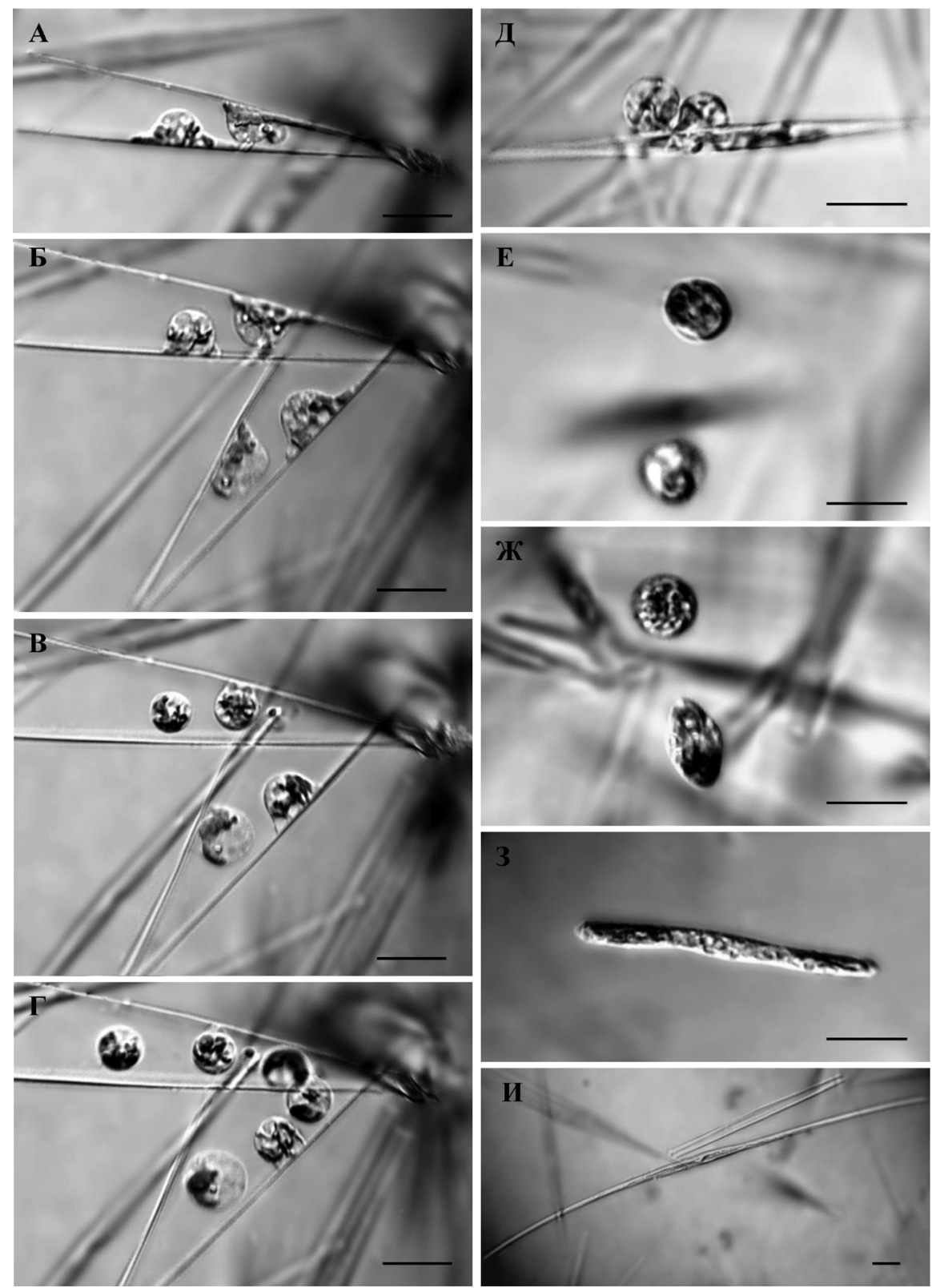

Рис. 4. Гаметогенез и образование ауксоспор у Ulnaria acus: А - Г - стадии женского гаметогенеза, содержимое гаметангия поделилось в апикальной плоскости, образовав две гаметы, прикрепленные к створкам. Созревая, женские гаметы округляются и отделяются от створок гаметангия; в паре гамет это происходит не всегда синхронно; Д - мужские гаметы, которые после деления мужского гаметангия в трансапикальной плоскости, раздвигая створки клетки гаметангия и округляясь, «выходят» в среду; Е - 3 - стадии формирования ауксоспор; И - постинициальная клетка, апикальная длина которой более чем в два раза превышает длину гаметангиальной клетки. Масштаб: 20 мкм

Fig. 4. Gametogenesis and auxospore formation in Ulnaria acus: A $-\Gamma$ - female gametogenesis, female gametangium content divides in the apical plane giving rise to two gametes attached to the gametangial thecae. With time the gametes became rounded and finally detach from the thecae; development of the two gametes in the female gametangium was not completely synchronic; Д - male gametes, which after dividing of the male gametangium in the transapical plane, rounded, and went out one after another from the gametangium frustule pushing its valves apart; $Е-3$ - different stages of auxospore expansion; $И$ - initial cell is prominently longer than one of the cells of the parental clone. Scale $20 \mu \mathrm{m}$ 

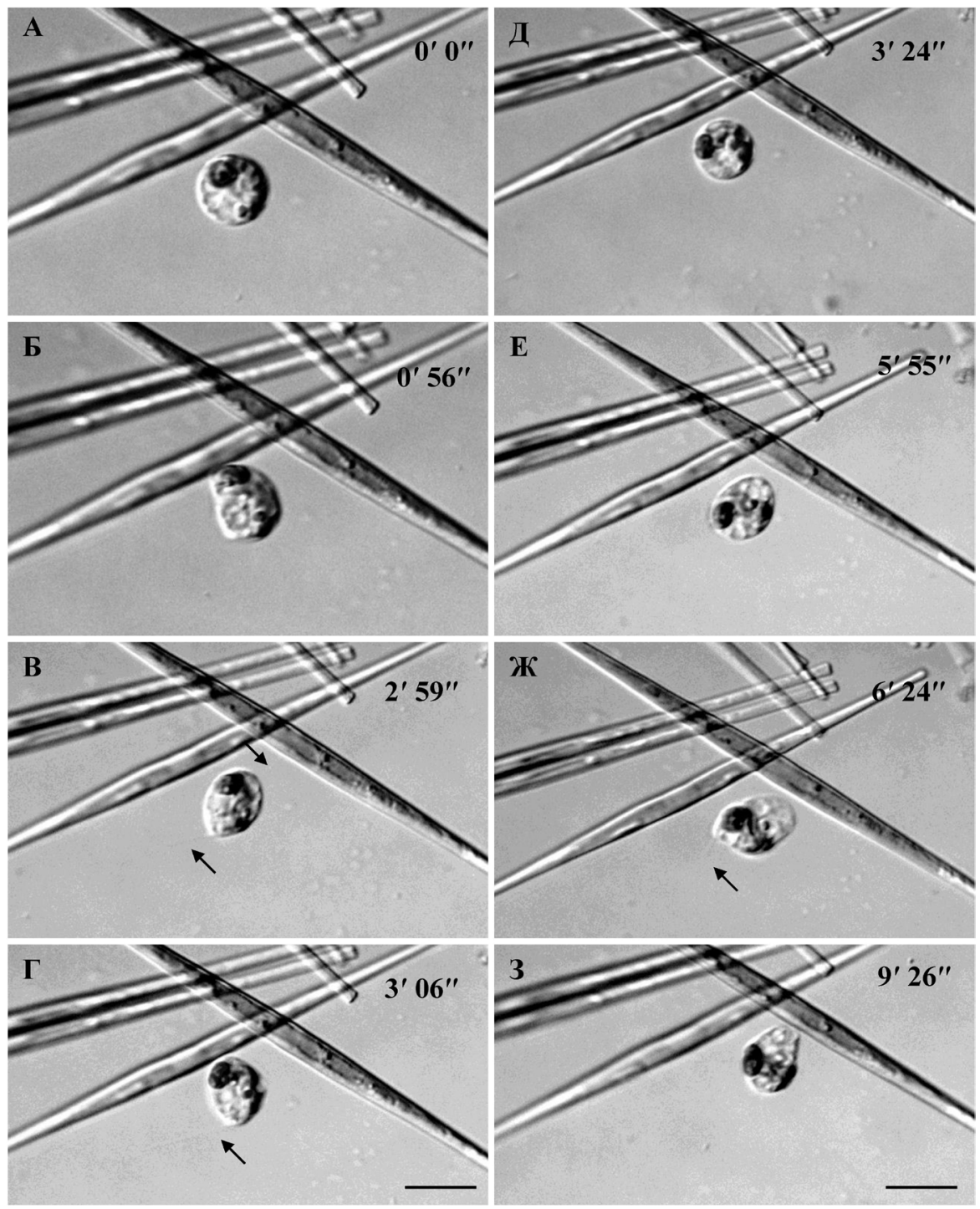

Рис. 5. Стадии движения гамет: А, Д - стадии покоя, гамета круглая, без движения; Б - Г, Е - 3 поверхность гаметы становится активной, гамета меняет свою форму, поворачивается и совершает небольшие движения, то приближаясь, то отдаляясь от створок соседних клеток. Стрелками показаны структуры, напоминающие псевдоподии. Масштаб: 20 мкм

Fig. 5. Gamete movement stages: А, Д - resting stages, gamete are nearly spherical without movement; Б $-\Gamma$, E - 3 - the gamete surface became active, the gamete deforms, turns and makes small movements, approaching and moving away from the cells valves. Arrows show pseudopodial-like structures. Scale $20 \mu \mathrm{m}$

гамет не требовалось, с гаметами из одного женского гаметангия могли слиться мужские гаметы из разных гаметангиев, причем расположенных на значительном расстоянии друг от друга и от женского гаметангия. После копуляции гамет формировалась шаровидная зигота, которая вскоре начинала удлиняться (рис. 4E-3). На ранних этапах формирующиеся ауксоспоры имели удлиненную, слегка изогнутую форму (рис. 4И). Удлинение ауксоспоры происходило одновременно в обе стороны вдоль апикальной оси (биполярно), 
хотя иногда наблюдалось ненормальное удлинение растущей ауксоспоры только с одного конца (в таком случае формирование инициальных клеток не случалось, ауксоспора разрушалась). Ауксоспоры не имели тесной связи со створками гаметангиев и могли формироваться как вблизи створок женского гаметангия, так и поодаль.

\section{Система скрещивания}

За три года наблюдений и экспериментов по скрещиванию ни у одного клона $U$. acus не было обнаружено способности к гомоталлическому воспроизведению, тогда как в смесях клонов противоположного пола при соблюдении необходимых условий (экспоненциально растущая культура, температура окружающей среды $15-20{ }^{\circ} \mathrm{C}$, длина светового дня 8-12 ч) практически во всех случаях наблюдался гетероталлический половой процесс (табл. 2). Изначально для получения полового воспроизведения нами было использовано всего три клона, выделенных из природной популяции оз. Фролиха (W=Wild), которые успешно вступили в половой процесс и дали жизнеспособное потомство. Инициальные клетки - потомки первого поколения (F1), образовавшиеся в результате гетероталлического воспроизведения, были введены в культуру. После уменьшения клеток до размеров, при которых клоны стали сексуальноиндуцибельными (от 194 и меньше мкм), потомки также свободно вступили в половой процесс между собой и дали активное гамето- и ауксоспорообразование при возвратном скрещивании с родительскими клонами, что позволило определить их пол (табл. 2).

\section{Обсуждение}

Полученные данные показывают, что Ulnaria acus относится к категории IA2b в системе Гайтлера (Geitler, 1973), классифицирующей модели полового воспроизведения и ауксоспорообразования у диатомовых водорослей. Такой тип полового процесса, при котором в разных гаметангиях образуются

Таблица 2. Воспроизведение в смешанных посевах Ulnaria acus

Table 2. Results of mating experiments between Ulnaria acus clones

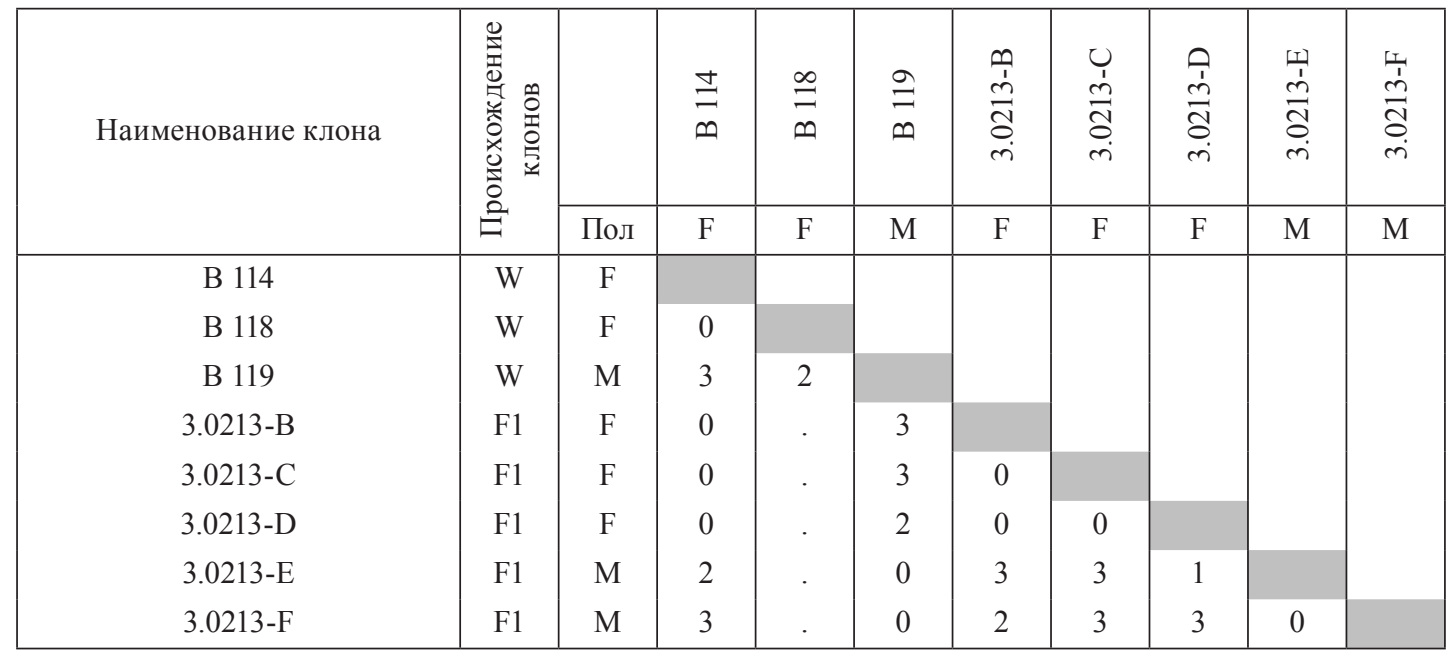

Примечание: частота (обилие) случаев воспроизведения оценена в баллах: 0 - нет воспроизведения, 1 - редкие случаи, 2 - нередко, 3 - массовое воспроизведение, - - не проверяли; W - клоны, выделенные из природной популяции, F1 потомки первого поколения; F - клоны женского пола, М - клоны мужского пола. 
гаметы разного типа (в женском - две пассивные, в мужском - две активные), еще называют цис-анизогамией (Mann, 1993).

Во многих основных чертах система скрещивания вида схожа с описанной у близкородственной Ulnaria ulna (ранее Synedra ulna) (Kützing) Aboal (Geitler, 1939; Podunay et al., 2014), а также Tabularia fasciculata (C. Agardh) D.M. Williams \& Round и T. tabulata (C. Agardh) Snoeijs (Рощин, 1994; Davidovich et al., 2010; Davidovich, Davidovich, 2011). Однако в отличие от этих близкородственных видов у $U$. acus за три года содержания в культуре и проведения экспериментов по скрещиванию не было отмечено случаев гомоталлического воспроизведения ни в мужских, ни в женских клонах. Отсутствие внутриклонового воспроизведения не является чем-то уникальным, у бесшовных оно известно, напримep, y Licmophora communis (Heiberg) Grunow (Chepurnov, Mann, 2004).

Жизненный цикл U. acus типичен для большинства бесшовных пеннатных диатомовых водорослей. Клетки приобретают способность к половому воспроизведению при достижении апикальной длины 194 мкм, что составляет 54 \% от максимального видоспецифического размера (360 мкм). Это соответствует общей тенденции у диатомовых водорослей (Davidovich, 2001). Клетки, апикальная длина которых стала меньше 62 мкм (что соответствует $17 \%$ от максимального видоспецифического размера), оказались неспособными более вступать в половое воспроизведение. При этом зависимость длины инициальных клеток от родительских практически отсутствует (коэффициент корреляции 0,35). У $U$. ulna такая корреляция еще слабеe (Podunay at al., 2014), тогда как у $T$. fasciculata она присутствовала с коэффициентом корреляции 0,655 (Davidovich et al., 2010).
Гаметогенез у U. acus начинался с образования в клетке большого количества вакуолей, эта особенность также была отмечена у U. ulna (Geitler, 1939). Для гамет, которые продуцируются мужскими и женскими клонами $U$. acus, на поздних этапах характерны морфологическая изогамия при поведенческой анизогамии. На ранних этапах гаметогенеза женские и мужские гаметангии U. acus очень хорошо отличимы по способу формирования гамет. Гаметы, которые продуцируются гаметангиями мужского типа, способны совершать вращательные и хаотические поступательные движения, тогда как гаметы, сформированные гаметангиями женских клонов, остаются неподвижными. Поведенческая анизогамия мужских и женских клонов характерна и для других видов диатомовых: U. ulna (Podunay at al., 2014), T. tabulata (Davidovich, Davidovich, 2011), L. communis (Chepurnov, Mann, 2004), Sellaphora pupula (Kütz.) Mereschk. (Mann et al., 1999).

Для мужских гамет изучаемого вида также показан способ движения гамет, связанный с формированием псевдоподиеподобных выростов. На данный момент мы не можем точно назвать тип псевдоподий. У Pseudostaurosira trainorii E.A.Morales, как было установлено (Sato et al., 2011), псевдоподии содержат микротрубочки. Движение мужских гамет U. acus схоже с наблюдавшимся у близкородственных видов U. ulna (Podunay et al., 2014), T. tabulata и T. fasciculata (Davidovich et al., 2012).

В заключение следует отметить, что впервые описанные половое воспроизведение и система скрещивания $U$. acus не только дают принципиально новое знание о биологии вида, но важны также с точки зрения его эффективного культивирования и использования в биотехнологических целях (Davidovich et al., 2015). 
Работа выполнена при поддержке гранта РНФ 14-14-00555.

\section{Список литературы}

Бедошвили Е.Д., Лихошвай Е.В., Грачев М.А. (2007) Ультраструктура диатомеи Synedra acus subsp. radians по данным трансмиссионной электронной микроскопии после мягкого растворения кремнезема. Известия академии наук, Серия Биологическая, 3: 367-371 [Bedoshvili E.D., Likhoshway Y.V., Grachev M.A. (2007) Ultrastructure of diatom Synedra acus subsp. radians as revealed by transmission electron microscopy after mild silica dissolution. Biology Bulletin [Izvestiya Rossiiskoi Akademii Nauk, Seriya Biologicheskaya], 3: 367-371 (in Russian)]

Бедошвили Е.Д., Попкова Т.П., Лихошвай Е.В. (2009) Ультраструктура хлоропластов нескольких видов диатомовых водорослей из разных классов. Цитология, 51 (4): 346-357 [Bedoshvili Ye.D., Popkova T.P., Likhoshway Ye.V. (2009) Chloroplast ultrastructure in some diatoms from different classes. Cytology [Citologiya], 51 (4): 346-357 (in Russian)]

Гайсина Л.А., Фазлутдинова А.И., Кабиров Р.Р. (2008) Современные методы выделения и культивирования водорослей. Уфа, Изд-во БГПУ, 152 с. [Gaysina L.A., Fazlutdinova I.A., Kabirov R.R. (2008) Modern methods of isolation and cultivating of algae. Ufa, Bashkir State Pedagogical University, 152 p. (in Russian)]

Поповская Г.И., Генкал С.И. (1998) К экологии и морфологии байкальской Synedra acus subsp. radians (Kütz.) Skabitsch. (Bacillariophyta). Биология внутренних вод, 1: 92-96 [Popovskaya G.I., Genkal S.I. (1998) On the ecology and morphology of the Baikal Synedra acus subsp. radians (Kütz.) Skabitsch. (Bacillariophyta). Inland Water Biology [Biologiya vnutrennih vod], 1: 92-96 (in Russian)]

Рощин А.М. (1994) Жизненные циилль диатомовых водорослей. Киев, Наукова думка, 171 с. [Roshchin A.M. (1994) Life cycles of diatoms. Kiev, Naukova Dumka, 171 p. (in Russian)]

Федин Л.А., Барский И.Я. (1971) Микрофотография. Л., Наука, 220 с. [Fedin L.A., Barsky I.J. (1971) Microphotography. Leningrad, Nauka, 220 p. (in Russian)]

Chepurnov V.A., Mann D.G. (2004) Auxosporulation of Licmophora communis (Bacillariophyta) and a review of mating systems and sexual reproduction in araphid pennate diatoms. Phycological Research, 52 (1): 1-12

Davidovich N.A., Davidovich O.I., Podunai Yu.A., Shorenko K.I., Kulikovskii M.S. (2015) Reproductive properties of diatoms significant for their cultivation and biotechnology. Russian Journal of Plant Physiology, 62 (2): 153-160

Davidovich N.A. (2001) Species specific sizes and size range of sexual reproduction in diatoms. Proc. 16th Int. Diatom Symp. (25 Aug. - 1 Sept. 2000). Athens, University of Athens, p. 191-196

Davidovich N.A., Davidovich O.I. (2011) Sexual reproduction and mating system of the diatom Tabularia tabulata (C. Agardh) Snoeijs (Bacillariophyta). International Journal on Algae, 13 (1): $18-36$

Davidovich N.A., Kaczmarska I., Ehrman J.M. (2010) Heterothallic and homothallic sexual reproduction in Tabularia fasciculata (Bacillariophyta). Fottea, 10 (2): 251-266

Davidovich N.A., Kaczmarska I., Karpov S.A., Davidovich O.I., MacGillivary M.L., Mather L. (2012) Mechanism of male gamete motility in araphid pennate diatoms from the genus Tabularia (Bacillariophyta). Protistologica, 163(3): 480-494 
Galachyants Yu.P., Morozov A.A., Mardanov A.V., Beletsky A.V., Ravin N.V., Petrova D.P., Likhoshway Ye.V. (2012) Complete chloroplast genome sequence of freshwater araphid pennate diatom alga Synedra acus from Lake Baikal. International Journal of Biology, 4 (1): 27-35

Geitler L. (1939) Die Auxosporenbildung von Synedra ulna. Berichte der Deutschen Botanischen Gesellschaft, 57: 432-436

Geitler L. (1973) Auxosporenbildung und Systematik bei pennaten Diatomeen und die Cytologie von Cocconeis-Sippen. Österreichische Botanische Zeitschrift, 122: 299-321

Grachev M.A., Vorobyova S.S., Likhoshway Ye.V., Khlystov O.M., Bezrukova E.V., Veinberg E.V., Goldberg E.L., Granina L.Z., Kornakova E.G., Lazo F.I. (1998) A high-resolution diatom record of the palaeoclimates of East Siberia for the last 2.5 My from Lake Baikal. Quaternary Science Reviews, 17: $1101-1106$

Grachev M., Sherbakova T., Masyukova Y., Likhoshway Y. (2005) A potential zinc binding motif in silicic acid transport proteins of diatoms. Diatom Research, 20: 409-411

Grachev M.A., Denikina N.N., Belikov S.I., Likhoshway Ye.V., Usol'tseva M.V., Tikhonova I.V., Adel'shin R.V., Kler S.A., Shcherbakova T.A. (2002) Elements of the active center of silicon transporters in diatoms. Molecular Biology, 36 (4): 534-536

Kulikovskiy M., Lange-Bertalot H., Annenkova N., Gusev E., Kociolek J.P. (2016) Morphological and molecular evidence support description of two new diatom species from the genus Ulnaria in Lake Baikal. Fottea, Olomouc, 16(1): 34-42

Lange-Bertalot H., Ulrich S. (2014) Contributions to the taxonomy of needle-shaped Fragilaria and Ulnaria species. Lauterbornia, 78: 1-73

Mann D.G. (1993) Patterns of sexual reproduction in diatoms. Hydrobiologia, 269/270: 11-20

Mann D.G., Chepurnov V.A. (2004) What have the Romans ever done for us? The past and future contribution of culture studies to diatom systematic. Nova Hedwigia, 79: 237-291

Mann D.G., Chepurnov V.A., Droop S.J.M. (1999) Sexuality, incompatibility, size variation, and preferential polyandry in natural populations and clones of Sellaphora pupula (Bacillariophyceae). Journal of Phycology, 35: 152-170

Petrova D.P., Khabudaev K.V., Marchenkov A.M., Galachyants Yu.P., Kalyuzhnaya O.V., Zakharova Yu.R., Likhoshvai E.V., Grachev M.A. (2013) Aquaporin-like protein of the diatom Synedra acus. Doklady Biochemistry and Biophysics, 448 (1): 5-8

Podunay Yu.A., Davidovich O.I., Davidovich N.A. (2014) Mating system and two types of gametogenesis in the fresh water diatom Ulnaria ulna (Bacillariophyta). Algologia, 24 (1): 3-19

Ravin N., Galachyants Yu.P., Mardanov A.V., Beletsky A.V., Petrova D.P., Sherbakova T.A., Zakharova Yu.R., Likhoshway Ye.V., Skryabin K.G., Grachev M.A. (2010) Complete sequence of the mitochondrial genome of a diatom alga Synedra acus and comparative analysis of diatom mitochondrial genomes. Current Genetics, 56: 215-233

Sato S., Beakes G., Idei M., Nagumo T., Mann D.G. (2011) Novel sex cells and evidence for sex pheromones in diatoms. PLoS ONE, 6 (10): e26923

Vereshchagin A.L., Glyzina O.Yu., Basharina T.N., Safonova T.A., Latyshev N.A., Liubochko S.A., Korneeva E.S., Petrova D.P., Annenkov V.V., Danilovtseva E.N., Chebykin E.P., Volokitina N.A., Grachov M.A. (2008) Culturing of a fresh-water diatomic alga Synedra acus in a 100-1 photobioreactor and analysis of biomass composition. Biotechnology in Russia, 4: 77-90 
Zakharova Yu.R., Adel'shin R.V., Parfenova V.V., Bedoshvili Ye.D., Likhoshway Ye.V. (2010) Taxonomic characterization of the microorganisms associated with the cultivable diatom Synedra acus from Lake Baikal. Microbiology, 79 (5): 688-695 